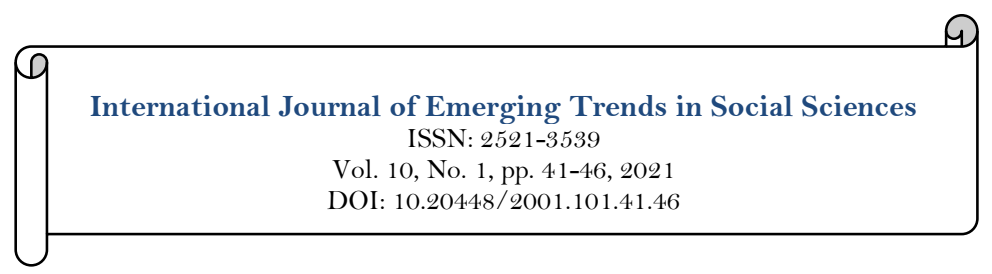

\title{
The Impact of Emotional Intelligence on Job performance in the Gulf Region
}

\author{
Fayez Hamed Al Shdaifat ${ }^{1}$ \\ Adel Ali Yassin Al Zyoud ${ }^{2 *}$ \\ 'Al Ain University of Science and Technology, UAE
'Applied Science University, Kingdom of Bahrain. \\ Email:adel.alzyoud@asu.edu.bh
}

\section{Abstract}

The aim of this research is to discover the impact of Emotional Intelligence (EI) on job performance among the employees in the gulf region. The results of recent researches indicate that EI is related positively with vital work manners. However, studies on EI have largely been conducted in the business field and in western countries. Therefore, there is a scarcity on EI studies in the context of public setting in the Gulf region, particularly in the medical field. A sample of 120 employees (doctors) was selected for this study, from which data was obtained. Regression analysis was applied as a statistical test to analyze the data. The findings revealed a significant relationship between emotional intelligence and job performance among doctors. This indicates that the increase of emotional intelligence will increase job's performance. As previously mentioned, this study can help the managements and academics better understand the relationship among the variables. It can also help professionals in organization enhanced understand the relationship amongst these factors.
Keywords:

Emotional intelligence

Job performance

Gulf region

Doctors.

Licensed:

This work is licensed under a

Creative Commons Attribution 4.0

License.

Publisher:

Scientific Publishing Institute

Received: 4 February 2021

Revised: 8 March 2021

Accepted: 22 March 2021

Published: 2 April 2021

Corresponding Author

Funding: This study received no specific financial support.

Competing Interests: The authors declare that they have no competing interests.

\section{Introduction}

Job performance is a value referencing development because of its essential job in both worldwide and cross country work environment conditions. As indicated by Sri Ramalu (2010), the origination of job performance is perceived at the public level yet it's encouraging at the worldwide level remaining parts unclear. Its importance includes the two people and associations (Campbell, 1999), since task accomplishment and elite can prompt fulfillment.

Added to this, emotional Intelligence (EI) is an expanding region of study and it comes to be dynamically essential in perceiving how individuals carry on. EI improves comprehension of sentiments and their impact on conduct. Individuals who have a solid feeling of sincerely wise will have a strong sense to mindfulness, perceiving their own sentiments when they experience them (Estrada, Monferrer, Rodríguez, \& Moliner, 2021).

They are additionally ready to recognize feelings in others by understanding their own feelings and those of others. In this manner, they can oversee enthusiastic prompts and data to decide (Robbins \& Judge, 2016).

Salovey and Mayer (1990) characterized passionate insight (EI) as the ability to control the emotions just as impression of others and recognize among them to manage their reasoning and exercises.

Mayer, Salovey, and Caruso (2000) characterized EI as the accompanying: (a) the capacity to precisely and adaptively see, assess other than exact sentiments; (b) the capacity toward get sensation and enthusiastic 
information; (c) the capacity to reveal and produce passionate state to encourage scholarly alongside versatile exercises; and (d) the ability to direct fervors in oneself as well as in others also. Adding to this, it is the ability to accomplish exact scholarly dependent on opinions, and utilizing passionate information to create thought (Mayer, Roberts, \& Barsade, 2008). Also, Bagshaw (2000) characterized EI as the capacity to comprehend and identify with individuals.

EI can be learned and improved in the work environment. A specialist's conduct can be improved with regards to EI, premier to better individual performance. EI comparably can extend director's policymaking skills (Weston, 2010); (Gondal \& Husain, 2013) found that EI impacts the ideal style of battle diligence by laborers (specialists), along these lines will assist with adding to a superior perceiving of job performance.

\section{Literature Review}

The idea of passionate insight has become a mainstream point in the mental writing and has pulled in a large part of the public's consideration as of late (Yoke \& Panatik, 2015). Association requires relational collaborations to achieve its objectives, and most positions require the capacity to oversee feelings.

EI can give people solid agreement, to allot rules for current performance and give an interaction to social change, prompting performance improvement. Weston (2010) said that an instinctive administrator has unique abilities that can be more significant in a powerfully advancing climate. There are four elements of EI: (a) "self-emotion appraisal" (SEA) - to have better than average, certain sentiments more often than not, comprehend one's own feelings and emotions; (b) "others' emotion appraisal" (OEA) - know companions' feelings from their conduct and perception and be delicate to the sensations of others' feelings; "use of emotion" (UOE) - to set objectives and empower one self and make a decent attempt to accomplish them and "regulation of emotion "(ROE) - to control one's own feelings, soundly handle challenges and be quiet when fomented (Ping \& Yue, 2010).

A person's EI can be believed to direct relational connections however regardless of this, numerous directors in the work environment don't really want to manage intense subject matters (Ping \& Yue, 2010). Examination by Cooper (1997) found that feelings have fruitful results and can drive steadfastness, responsibility and trust, just as achievement in the individual circle (Cooper, 1997). It is accepted that in the event that somebody has the best preparing on the planet, and high culture knowledge level, the individual would in any case not make a decent specialist without EI.

Additionally, Goleman (1998) study showed that enthusiastic knowledge is more indispensable on all levels in the work environment compare to functional abilities. It likewise empowers works variation (Huy, 1999). In adding, clinicians who have set up related abilities comprehend their own feelings, perceive the others' feelings, and practice feelings to invigorate versatile practices (Mayer et al., 2000). Schutte et al. (1998) contended that enthusiastic knowledge is identified with passionate results, for instance, more unfortunate degrees of despondency and more sure perspectives. Passionate insight is additionally emphatically connected with pregnancy control and life fulfillment and damagingly associated with despondency (Martinez-Pons, 1997). As needs be, chiefs' act of feelings ideally relates with specialist fulfilment (Kafetsios, Nezlek, \& Vassiou, 2011). In an examination by Kong, Zhao, and You (2012) in China, the members were 678 Chinese grown-ups in the age scope of 18-35 years. The scale utilized comprised of four measurements predictable with Mayer and Salovey (1997) meaning of EI: SEA, OEA, ROE and UOE. Results uncovered that Chinese developed individual with more prominent positions of EI required a development in the course of their life fulfillment. A connected exploration by Affandi and Raza (2013) in Pakistan investigated the relationship among chiefs EI and specialist performance. Contained of 92 doctors working in various emergency clinics across Pakistan. Results showed that pioneers' feeling is decidedly connected to specialist performance.

In the mean time, Nawi, Redzuan, and Hamsan (2012) embraced an exploration in Malaysia and their discoveries uncovered that character attributes have a positive and critical connection with generally speaking EI among school pioneers. In a connected report, Cartwright and Pappas (2008) reasoned that EI may have suggestions for the choice and improvement of representatives (specialists), especially those associated with unpleasant positions.

Notwithstanding the above examinations (Hassan \& Diallo, 2013) zeroed in on ostracizes in five private universities in Malaysia, with an example including 100 respondents, and tracked down a positive connection among EI and job performance of exiles. Sy, Tram, and O'hara (2006) inspected the connection among EI and performance of workers and found that representatives' EI is related with work performance decidedly. Past encounters profoundly impact EI. A person's EI shows how the individual in question communicates with others and gets oneself to effectively associate with individuals; in this manner, they change their conduct towards task accomplishment (McFarland, 2005). In Pakistan, Shahzad, Sarmad, Abbas, and Khan (2011) led an investigation and tracked down a positive connection among EI and worker performance. EI improves work performance by empowering individuals to work adequately (Seibert, Kraimer, \& Liden, 2001) and to direct their feelings to adapt to pressure and perform viably under work tension. In their investigation, Bhalla and Nauriyal (2004) revealed that EI is valuable for comprehension and anticipating a person's work performance. Essentially, Lyons and Schneider (2005) inspected the connection between capacity based parts of EI aspects and performance under pressure, and set that undeniable degrees of EI advance improved performance levels. 
Along these lines, EI is affirmed to be a solid indicator of career performance (Cote \& Miners, 2006; Shahhosseini, Silong, Ismaill, \& Uli, 2012). Vahidi, Areshtanab, and Bostanabad (2016) researched the connection among EI and career performance. The outcomes uncovered that workers (doctor's) EI is decidedly identified with fulfillment and job performance. Moreover, Khokhar and Kush (2009) found a connection among EI and viable occupation performance. The discoveries of the examination uncovered that heads with undeniable level EI showed fulfillment and better nature of job performance. Notwithstanding position performance, other conduct results have stood out for researchers and occupation fulfillment is one of them. Past examinations have researched the connection among EI and occupation fulfillment. For example, Lam and O'Higgins (2012) analyzed the connection among EI and work fulfillment. The outcomes showed that people (doctor's) with high EI are probably going to have undeniable degrees of work fulfillment. Additionally, Kafetsios and Zampetakis (2008) and Najafi and Mousavi (2012) did an investigation on the connection among EI and occupation fulfillment. The outcomes uncovered that a critical relationship exists among EI and occupation fulfillment. Khalili (2011) then again, tracked down a critical and positive connection among EI and hierarchical responsibility. The EQ of SEA, OEA, UOE and ROE are vital to the workers (specialists) (Ping \& Yue, 2010). Investigations of this type likewise incorporate (Affandi \& Raza, 2013) who found that EI is emphatically connected to nature of work life. Specialists who utilize their feelings cleverly consistently fabricate great connection with others by giving them accommodating climate, which brings about effective change and occupation fulfillment (Affandi \& Raza, 2013). Akerjordet and Severinsson (2008) said that specialists' EI encourages and propels others and establishes a solid climate. Rose (2007) presumed that social holes in new conditions ought to be crossed over to achieve the mission and subsequently, working with various societies expects affectability to social contrasts.

Comparable, the drive of this exploration is to examine the effects of passionate insight as most prominent importance on the planet. In making the progress of the business, workers' exhibition is considered as fundamental highlights in an association yet there is a shortage of studies in such manner. To close, it is fundamental for take a minding of a choice of perspectives on enthusiastic insight and occupation performance in the working environment.

\section{Methodology \\ 3.1. Participants}

The respondents were doctors from different selected hospitals located in Gulf countries (United Arab Emirates and Bahrain). The population of the study was selected from Gulf regions using random sampling technique. The population was 205 and the sample size was guided by Krejcie and Morgan (1970) table for determining sample size from a given population, and the appropriate sample size was 135 . The data collection instrument was questionnaire developed and validated by a group of experts. All items were answered using five point Likert scale ranging from 'strongly disagree' to 'strongly agree'.

The sample consisted of 101 males $(74.8 \%)$ and 34 females $(25.2 \%)$. On the age, the more of them were in the age of 36 to 50 years old $(47.4 \%)$, and 51 to 65 years old $(38.5 \%)$. On the level of education, statistics displayed that the respondent were university graduates with bachelor's degree. On the extent of occupation, most of the them $(49.6 \%)$ had been working for over 10 years.

\subsection{Variable Measurement}

EI scale developed by Wong and Law (2002) consisting of 16 items. EI had four components: "SEA; ROE; OEA; and UOE”. A study by Kong et al. (2012) reported reliability alpha value of EI components was accepted. The reliability alpha value of all items was .89. The present study implemented a 4-item that was applied in the research of Carmeli (2003). In all items Factor loading was accepted.

\section{Results}

Results are shown in Table 1 "reliability test" disclosed that Cronbach's Alpha for job performance item was 0.81 , which point out that the internal consistency of the items with the samples was accepted. As for emotional intelligence, Cronbach's Alpha was at .77 for SEA, .70 for OEA and ROE, and .74 for UOE which also point out a satisfactory and good internal consistency reliability of scale with the sample (Sekaran \& Bougie, 2010). Overall, the reliability for all the variables was acceptable.

Table-1. Descriptive statistics, scale reliabilities, and correlations of study variables $(\mathrm{n}=135)$.

\begin{tabular}{l|c|c|c|c|c|c|c|c}
\hline Variable & $\mathbf{M}$ & $\mathbf{S D}$ & $\boldsymbol{\alpha}$ & $\mathbf{1}$ & $\mathbf{2}$ & $\mathbf{3}$ & $\mathbf{4}$ & $\mathbf{5}$ \\
\hline Self-emotion appraisal & 3.84 & 0.57 & 0.77 & - & & & & \\
\hline Others' Emotion Appraisal & 3.80 & 0.55 & 0.70 & $0.42^{*} *$ & - & & & \\
\hline Use of Emotion & 3.82 & 0.64 & 0.74 & 0.01 & 0.09 & - & & \\
\hline Regulation of Emotion & 3.93 & 0.62 & 0.70 & 0.11 & 0.11 & $0.47^{* *}$ & - & \\
\hline Job Performance & 3.80 & 0.74 & 0.81 & $0.29 * *$ & $0.36^{* *}$ & $0.43^{*} *$ & $0.58^{*} *$ & - \\
\hline
\end{tabular}


Table 2 shows the effect of the autonomous factors which are "self-feeling examination, others' feeling evaluation, utilization of feeling and guideline of feeling" on the reliant variable. "Occupation performance" as it is clarified by the $\mathrm{R}$ Square estimation of .49, demonstrates that $49 \%$ of the fluctuation was fundamentally clarified by the components of free factor towards work performance. The table shows $\mathrm{F}$ estimation of 30.92 , critical at 0.000 levels.

Table-2. Regression results for the effects of self-emotion appraisal, others' emotion appraisal, use of emotion and regulation of emotion on job performance.

\begin{tabular}{|c|c|c|c|c|c|}
\hline \multirow[t]{2}{*}{ Model } & \multicolumn{2}{|c|}{$\begin{array}{c}\text { Unstandardized } \\
\text { Coefficients }\end{array}$} & \multirow{2}{*}{$\begin{array}{c}\text { Standardized } \\
\text { Coefficients }\end{array}$} & \multirow[t]{2}{*}{$\mathbf{t}$} & \multirow[t]{2}{*}{$\begin{array}{c}\text { Significan } \\
t\end{array}$} \\
\hline & $\boldsymbol{\beta}$ & Std. Error & & & \\
\hline (Constant) & -1.20 & 0.48 & - & -2.50 & $0.01^{* *}$ \\
\hline Self-emotion appraisal & 0.18 & 0.09 & 0.14 & 1.99 & $0.04^{* *}$ \\
\hline Others' Emotion Appraisal & 0.31 & 0.09 & 0.23 & 3.27 & $0.001^{* *}$ \\
\hline Use of Emotion & 0.27 & 0.07 & 0.23 & 3.44 & $0.001^{* *}$ \\
\hline Regulation of Emotion & 0.55 & 0.08 & 0.46 & 6.71 & $0.000^{* * *}$ \\
\hline
\end{tabular}

Further, from the relapse investigation "regression analysis", it was tracked down that autonomous factors fundamentally added to job performance. It was gotten from the importance level of $\mathrm{p}<0.05$. Among the factors, the most noteworthy beta worth comes from guideline of feeling (ROE), which is $(\mathrm{B}=.46 ; \mathrm{p}<.000)$, at that point others' feeling examination and utilization of feeling $(\mathrm{B}=.23 ; \mathrm{p}<.001)$. Henceforth, guideline of feeling (ROE), others' feeling examination (OEA) and utilization of feeling (UOE) ought to be stressed individually to accomplish high job performance of representatives.

\section{Discussions, Limitations and Directions for Future Research}

Emotional intelligence improves innovational creativeness in people and as a conclusion, assists in the improving doctors' job performance (Ganji, 2011). On the other hand, several studies disclosed that doctors' emotional intelligence is moderate and high, which was in line with the outcomes of these studies (e.g., (Codier, Kooker, \& Shoultz, 2008; Vahidi et al., 2016)). Roughly dissimilarities may be because of educational and cultural doctors' work setting in a number of societies and measurement by dissimilar tools. In this regard, more of analyses done previously supported the connection among the two variables such as, emotional intelligence as well job performance (e.g., (Alonazi, 2020; Day \& Carroll, 2004; Harris, 2009; Jacques, 2009; Millet, 2007; Rieck, 2008)). Furthermore, extremely emotionally intelligent doctors are more on time and take extreme inventiveness on the job, and they put much hard work to expanding their jobs and have enhanced work performance as linked to their matching part.

A few constraints "limitations" of the examination are referenced in this part. To begin with, the received cross-sectional exploration plan of this investigation renders troublesome any obstruction on the causative idea of the analyzed connections. Also, the ability to distinguish arbitrators may have been diminished by the moderately little example size and the inconsistent example sizes across gatherings (for example male versus female). Different constraints of our examination concern the assortment of information from one emergency clinic. For future exploration, since this examination was absolutely quantitative in its information assortment, utilizing poll sent through email, thus, it is smarter to supplement the technique with a subjective one, (for example, vested party interviews) to catch components of subjectivities in the reactions given by the respondents. This is especially valid for research including parts of feelings and discernments, which organized survey neglects to catch satisfactorily.

\section{Conclusion}

To conclude the paper shows that job performance is influenced by emotional intelligence. The empirical evidences also support the research that doctors have emotional intelligence in the hospitals. To sum up, it can be said that due to increasing years in the service, senior doctors are more compatible and emotionally intelligent than the junior doctors.

Organizations ought to perceive the critical part of emotional intelligence in creating human resources as this prompts high-performing labor force. Uplifting feedback of a sincerely savvy climate will empower the improvement of an assistance arranged environment, which is genuine in nature, and consequently more viable.

\section{References}

Affandi, H., \& Raza, N. (2013). Leadersee emotional intelligence and its outcomes. Interdisciplinary Journal of Contemporary Research in Business, 7(5), 279-297.

Akerjordet, K., \& Severinsson, E. (2008). Emotionally intelligent nurse leadership: A literature review study. Journal of Nursing Management, 16(5), 565-577.Available at: https://doi.org/10.1111/j.1365-2834.2008.00893.x. 
Alonazi, W. B. (2020). The impact of emotional intelligence on job performance during COVID-19 crisis: A cross-sectional analysis. Psychology Research and Behavior Management, 13, 749-757.Available at: https://doi.org/10.2147/prbm.s263656.

Bagshaw, M. (2000). Emotional intelligence-training people to be affective so they can be effective. Industrial and Commercial Training, 32(2), 61-65.Available at: https://doi.org/10.1 108/00197850010320699.

Bhalla, S., \& Nauriyal, D. K. (2004). Emotional intelligence: The emerging paradigm in personnel dynamics. Psychological Studies-University of Calicut, 49(8), 97-106.

Campbell, J. P. (1999). The definition and measurement of performance in the new age. In D. R. Ilgen \& E. D. Pulakos (Eds.), The changing nature of performance: Implications for staffing, motivation, and development (pp. 399429). San Francisco, Calif: Jossey-Bass.

Carmeli, A. (2003). The relationship between emotional intelligence and work attitudes, behavior and outcomes: An examination among senior managers. Journal of Managerial Psychology, 18(8), 788-813.Available at: https://doi.org/10.1108/02683940310511881.

Cartwright, S., \& Pappas, C. (2008). Emotional intelligence, its measurement and implications for the workplace. International Journal of Management Reviews, 1O(2), 149-171.Available at: https://doi.org/10.1111/j.14682370.2007.00220.x

Codier, E., Kooker, B. M., \& Shoultz, J. (2008). Measuring the emotional intelligence of clinical staff nurses: An approach for improving the clinical care environment. Nursing Administration Quarterly, 32(1), 8-14.Available at: https://doi.org/10.1097/01.naq.0000305942.38816.3b.

Cooper, R. K. (1997). Applying emotional intelligence in the workplace. Training and Development, 51 (12), 31 1-38.

Cote, S., \& Miners, C. T. (2006). Emotional intelligence, cognitive intelligence, and job performance. Administrative Science Quarterly, 51(1), 1-28.Available at: https://doi.org/10.2189/asqu.51.1.1.

Day, A. L., \& Carroll, S. A. (2004). Using an ability-based measure of emotional intelligence to predict individual performance, group performance, and group citizenship behaviours. Personality and Individual Differences, 36(6), 1443-1458.Available at: https://doi.org/10.1016/s0191-8869(03)00240-x.

Estrada, M., Monferrer, D., Rodríguez, A., \& Moliner, M. Á. (2021). Does emotional intelligence influence academic performance? The role of compassion and engagement in education for sustainable development. Sustainability, 13(4), 1-18.Available at: https://doi.org/10.3390/su13041721.

Ganji, M. (2011). Emotional intelligence. Tehran: Savalan.

Goleman, D. (1998). The emotionally competent leader. In The Healthcare Forum Journal, 41(2), 36-38.

Gondal, U. H., \& Husain, T. (2013). A comparative study of intelligence quotient and emotional intelligence: Effect on employees' performance. Asian journal of Business management, 5(1), 153-162.Available at: https://doi.org/10.19026/ajbm.5.5824.

Harris, N. V. (2009). Is emotional intelligence the key to medical sales success?: The relationship between emotional intelligence and sales performance. Doctoral Dissertation, Capella University.

Hassan, Z., \& Diallo, M. M. (2013). Cross-cultural adjustments and expatriate's job performance: A study on Malaysia. International Journal of Accounting and Business Management, 1(1), 8-23.

Huy, Q. N. (1999). Emotional capability, emotional intelligence, and radical change. Academy of Management Revierw, 24(2), 325-345.Available at: https://doi.org/10.5465/amr.1999.1893939.

Jacques, E. T. (2009). The relationships between emotional intelligence and the academic performance and selection of a major of college students: Retrieved March 13. 2021 , from PreQuest database.

Kafetsios, K., Nezlek, J. B., \& Vassiou, A. (2011). A multilevel analysis of relationships between leaders' and subordinates' emotional intelligence and emotional outcomes. Journal of Applied Social Psychology, 41(5), $1121-1$ 144.Available at: https://doi.org/10.1111/j.1559-1816.2011.00750.x.

Kafetsios, K., \& Zampetakis, L. A. (2008). Emotional intelligence and job satisfaction: Testing the mediatory role of positive and negative affect at work. Personality and Individual Differences, 44(3), 712-722.Available at: https://doi.org/10.1016/j.paid.2007.10.004.

Khalili, A. (2011). Examining the relevance of emotional intelligence and organizational commitment among employees of small and medium enterprise in private sector. International Journal of Business and Management, 6(12), 180194.Available at: https://doi.org/10.5539/ijbm.v6n12p180.

Khokhar, C., \& Kush, T. (2009). Emotional intelligence and work performance among executives. Europe's Journal of Psychology, 5(1), 1-11.

Kong, F., Zhao, J., \& You, Y. (2012). Social support mediates the impact of emotional intelligence on mental distress and life satisfaction in Chinese young adults. Personality and Individual Differences, 53(4), 513-517.

Krejcie, R. V., \& Morgan, D. W. (1970). Determining sample size for research activities. Educational and Psychological Measurement, 30(3), 607-610.

Lam, C. S., \& O'Higgins, E. R. (2012). Enhancing employee outcomes: The interrelated influences of managers' emotional intelligence and leadership style. Leadership and Organization Development Journal, 33(2), 149-174.Available at: https://doi.org/10.1108/01437731211203465.

Lyons, J. B., \& Schneider, T. R. (2005). The influence of emotional intelligence on performance. Personality and Individual Differences, 39(4), 693-703.

Martinez-Pons, M. (1997). The relation of emotional intelligence with selected areas of personal functioning. Imagination, Cognition and Personality, 17(1), 3-13.Available at: https://doi.org/10.2190/68vd-dfxb-k5aw-pqay.

Mayer, J. D., \& Salovey, P. (1997). What is emotional intelligence? In Salovey, P. And Sluyter, D. (Eds.), Emotional Development, Emotional Literacy, and Emotional Intelligence. New York: Basic Books.

Mayer, J. D., Salovey, P., \& Caruso, D. (2000). Emotional intelligence meets traditional standards for an intelligence. Intelligence, 27(4), 267-298

Mayer, J., Roberts, R. D., \& Barsade, S. (2008). Emerging research in emotional intelligence. Annual Review of Psychology, $59(1), 507-536$. 
McFarland, M. (2005). Military cultural education. Military Review, 85(2), 62-69.

Millet, T. (2007). An examination of trait emotional intelligence factors: Their relationship to job satisfaction among police officers. (Doctoral Dissertation). Available from ProQuest Dissertations \& Theses Global database. (UMI No. 3283704).

Najafi, M., \& Mousavi, S. (2012). Studying the effect of emotional quotient on employee's job satisfaction (The Case of Isfahan University of Medical Sciences). Journal of Contemporary Research in Business, 4(2), 343-354.

Nawi, N., H., Redzuan, M., \& Hamsan, H. (2012). Inter relationship between emotional intelligence and personality trait of educator leaders. International Journal of Academic Research in Business and Social Sciences, 2(5), 223-237.

Ping, F. S., \& Yue, H. K. (2010). The mediating effects of leader member exchange (LMX) and team-member exchange (TMX) on the relationship between emotional intelligence, job satisfaction and job performance of employees. An Honours Degree Project Submitted to the School of Business in Partial Fulfilment of the Graduation for the Degree of Bachelor of Business Administration (honours).

Rieck, T. (2008). Emotional intelligence and team task performance: Does EI make a difference? Retrieved March 20. 2021, from PreQuest database.

Robbins, S. P., \& Judge, T. A. (2016). Organizational behavior (Global ed.). UK: Pearson Education.

Rose, J. (2007). Quiz on intercultural competence: Test your cultural awareness before traveling on business. Retrieved from: www.skillassessment.suite.101.com/.../quiz on intercultural competence.

Salovey, P., \& Mayer, J. D. (1990). Emotional intelligence. Imagination, Cognition and Personality, 9(3), 185-2 11.

Schutte, N. S., Malouff, J. M., Hall, L. E., Haggerty, D. J., Cooper, J. T., Golden, C. J., \& Dornheim, L. (1998). Development and validation of a measure of emotional intelligence. Personality and Individual Differences, 25(2), 167-177.

Seibert, S. E., Kraimer, M. L., \& Liden, R. C. (2001). A social capital theory of career success. Academy of Management Journal, 44(2), 219-237.

Sekaran, U., \& Bougie, R. (2010). Research method for business; A skill building approach (5th ed.). United Kingdom: A John Wiley and Sons, Ltd.

Shahhosseini, M., Silong, A. D., Ismaill, I. A., \& Uli, J. N. (2012). The role of emotional intelligence on job performance. International Journal of Business and Social Science, 3(21), 241-246.

Shahzad, K., Sarmad, M., Abbas, M., \& Khan, M. (2011). Impact of emotional intelligence (EI) on employee ees performance in telecom sector of Pakistan. African Journal of Business Management, 5(4), 1225-1231.

Sri Ramalu, S. (2010). Relationships between cultural intelligence, personality, cross-cultural adjustment and job performance. Doctoral Thesis, University Putra Malaysia, 2010. Retrieved from http://psasir.upm.edu.my/19661/.

Sy, T., Tram, S., \& O'hara, L. A. (2006). Relation of employee and manager emotional intelligence to job satisfaction and performance. Journal of Vocational Behavior, 68(3), 461-473.Available at: https://doi.org/10.1016/j.jvb.2005.10.003.

Vahidi, M., Areshtanab, H. N., \& Bostanabad, M. (2016). The relationship between emotional intelligence and perception of job performance among nurses in North West of Iran. Scientifica Journal, 2(6), 1-5.

Weston, H. A. (2010). Developing emotional intelligence (EQ) in the workplace. USA: University of Texas.

Wong, C.-S., \& Law, K. S. (2002). The effects of leader and follower emotional intelligence on performance and attitude: An exploratory study. The Leadership Quarterly, 13(3), 243-274.Available at: https://doi.org/10.1016/s10489843(02)00099-1.

Yoke, L. B., \& Panatik, S. A. (2015). Emotional intelligence and job performance among school teachers. Asian Social Science, 11(13), 227.Available at: https://doi.org/10.5539/ass.v11n13p227. 